INFO - 2194

UDK: 004:330.341.1(497.115)

Primljeno/Received: 2018-03-12

Preliminary Communication/ Prethodno priopćenje

\title{
THE RELATION BETWEEN INFORMATION TECHNOLOGY AND INNOVATION PROCESS IN SOFTWARE AND NOT SOFTWARE IN- DUSTRIES IN KOSOVO
}

\section{ODNOS IZMEĐU INFORMACIJSKE TEHNOLOGIJE I INOVACIJSKOG PROCESA U SOFTVERSKOJ I NE-SOFTVERSKOJ INDUSTRIJI NA KO- SOVU}

\author{
Emin Neziraj ${ }^{1}$, Afërdita Berisha-Shaqiri², Justina Shiroka Pula², Vasilika Ku- \\ $m e^{3}$, Besnik Krasniqi ${ }^{2}$ \\ Department of Business Administration, University "Haxhi Zeka", Kosovo ${ }^{1}$; Department of Management and Informatics, \\ Economic Faculty, University of Pristina, Pristina, Kosovo ${ }^{2}$;Department of Management and Economics, Economic Faculty, \\ University of Tirana, Tirana, Albania ${ }^{3}$ \\ Odjel za poslovnu administraciju, Sveučilište "Haxhi Zeka“, Kosovo1; Odjel za upravljanje i informatiku, Ekonomski \\ fakultet, Sveučilište u Prištini, Priština, Kosovo²; Odjel za menadžment i ekonomiju, Ekonomski fakultet, \\ Sveučilište u Tirani, Tirana, Albanija ${ }^{3}$
}

\section{Abstract}

Background and objective. This paper will focus on innovation process caused by information communication technology. The study in this paper discovers the relation of information technology in software and not software products service industry in innovation processes across their effect in the MBE-s in Kosovo. The main objective of the research study is to recognize the level of use of the new technology, respectively the new information technology in producing and service industry in Kosovo. Materials and Methods. The scientific methodology used in this work is the quantitative methodology with the deductive approach since it is intended to support the existing theory over the information technology and innovative processes. The quantitative data was use from empirical data of Statistical Agency Kosovo and authors own research. Results, the results of this study showing, the influences of information technology in innovation process with $p=0.23$. Conclusion Public and Private organizations should take appropriate steps to develop and improve new technologies

\section{Sažetak}

Pozadina i cilj. Ovaj će se rad usredotočiti na inovacijske procese uzrokovane informacijskokomunikacijskom tehnologijom. Studija u ovom radu otkriva odnos informacijske tehnologije $u$ softverskim i ne softverskih proizvoda uslužne industrije $u$ inovacijskim procesima preko njihovog učinka na MBE-e na Kosovu. Glavni cilj istraživanja je prepoznati razinu korištenja nove tehnologije, odnosno nove informacijske tehnologije u proizvodnoj i uslužnoj industriji na Kosovu. Materijali i metode. Znanstvena metodologija korištena u ovom radu je kvantitativna metodologija s deduktivnim pristupom budući da je namijenjena potpori postojećoj teoriji o informacijskoj tehnologiji i inovativnim procesima. Kvantitativni podaci korišteni su iz empirijskih podataka Agencije za statistiku Kosova i autora istraživanja. Rezultati ovog istraživanja pokazuju, utjecaje informacijske tehnologije $u$ inovacijskom procesu $\mathrm{s} \mathrm{p}=0.23$. Zaključak. Javne i privatne organizacije trebale bi poduzeti odgovarajuće korake za razvoj i poboljšanje novih tehnologija stvaranjem dugoročnih politika i strategija koje 
by creating long-term policies and strategies de- proizlaze iz potreba tržišta.

rived from market needs.

\section{Introduction}

In the fast changing business world today, innovation in information technology has become the mainstay for every seriously organization. Innovation in ICT has become increasingly complex due to changing customer needs, extensive competitive pressure and rapid information technology change.

The main purpose of research is to construct analytical framework for applied and create link between innovation and new products in ICT by produce sector in Kosovo. In other to this, it is necessary to analyze innovation ICT process in produce sector of Kosovo and finding new forms fo measurements ICT indicators on innovation process $/ \mathbf{1} /$.

Innovation caused by information technology is the driving force of economic development for each country and each company. Doing business on a constant innovation should lead to changes in the business process and ultimately increase efficiency in the production and service units. Kosovo as a state is trying to follow the trends of western markets even though the state on this issue is a lot less favorable compared to the markets of developed countries. Any serious company within its business sector (financial, IT and others) has a sector for research and development. The world economy has changed due to the greater development of information technology and enterprises are forced to survive in a modern global market economy characterized by the competition, the short life cycle of products and diversity of products. Many enterprises have difficulty in understanding the new information cause of their poor concept of investment, especially in information technology and modern management.

The innovative activity presents one of the main activities for the achievement of the organizational success of the enterprise, and for the overall and inclusive economic develop- ment of the country /2/. Nowadays, enterprises are not only required to do imitations but also to do adaptations and innovations in order to face the market competition and market turbulence.

The main objective of this study was to show the positive relation between variables innovation of information technology with all business activity in produce sector of Kosovo as a SEE country. This study gives us opportunity to recommend that all business must in their daily activity applied innovation in business process on the way to respond customer demands. Also regarding with research question of paper which is the level of placed technology innovation in field of production sector in Kosovo is very low and in relation between other SEE, OECD countries is in rapport 1:80. This paper strongly recommended that the state government policy must be oriented on increasing the innovation by giving the extra foundation for research and development for all business if they want to be part of development countries. Also and business must have special sector for research and development on the way to create new product and services.

\section{Theoreshtical background}

\subsection{The current application of it in business innovation activities}

When it comes to the application of IT technology in enterprises, the countries of Southeast Europe are lagging behind the countries of the European Union, especially when it comes to companies that carry out production. But when it comes to the financial sector, the situation is much different. The financial sector is generally adequately equipped with information technology, and as a result of investments to come from countries of the European Union, mostly from Austria, which has invested heavily in the banking sector across the countries of South Eastern Europe /3/. 
Information network today covers the entire globe, entering into every house, every factory and a social institution, linking land vehicles, aircraft, ships and every individual. At the same time, computers are in large banking systems, industrial complexes and traffic management as well as in washing machines, cars and toys $/ 4 /$.

The five main areas in which information technology completely changed the former life of work are:

- Information technology as a replacement for the calculator (Excel)

- Information technology as a substitute for the typewriter (Word)

- Information technology as a substitute for the archive (database)

- Information technology as a substitute for television (graphics and multimedia)

- Information technology as a substitute for the catalog (WWW)

Nowadays, the most common business data is processed on the computer, but the old ways of exchanging business information and documents in paper format are kept as well. If the capabilities of existing computer and telecommunications are exploit in the right way could greatly improve performance while reducing costs, providing better services and reduce the errors that occur in the work in the traditional manner. For ordering of goods or services via traditional, orders will be printed and mailed to the supplier, invoice is prepared, printed, and sent to the customer, and payment is made via check. Over $75 \%$ of all business documents printed by one organization is manually transcribed into another organization $/ 5 /$.

When the e-mail began to be used in the mid and late '60s, relatively few people have been computer trained. It is therefore not surprising to find that e-mail was dramatically overrun by fax, in the ' 80 s. The reasons were the ease of use, simple delivery of images and graphics, and input printed forms (forms, etc.). Large criticism to intensive use of the fax machine sent that was that it had removed the comput- er readability, which means the ability with which the recipient can automatically preserve, restore and manipulate your message. But today, with the ubiquity of computers, the advantages of e-mail are enormous, as it's been demonstrated with its fast-growing use. In addition to digital benefits, e-mail is a conversational medium. Even if it's not a spoken dialogue, it is much closer to speech than writing /5/.

Managing the development and operations of the modern economy shall be based on an efficient system of information on international and national markets and the market environment, as well as the capabilities of the business system on this basis /6/. The system information allows selection of optimal solutions in decision-making and reducing risk and uncertainty when you turn in the international exchange and the division of labor by detecting the legality of the international and national markets and the market environment. The impact of information technology on business performance is reflected in the quality of information, control, planning, to management and decision-making. It is important to point out two kinds of impact of information technology on the quality of the company as follows:

- Direct and easily measurable impacts - direct impacts include savings in resources (labor, materials, energy), time savings and simplification and streamlining of a business process in the company.

New technologies are the foundation for new products, provide a better connection with customers. The use of information technology is increasingly used in the formation of new products and services. Its main role is in changing business relationships, as well as improvement of business activities within the company /7/. New forms of information services (electronic ordering, buying at a distance, etc.) allow the implementation of a quality business policy /4/. Of course, this technology in countries is slowly starting to take on an important role in communicating on a relation 
producer-buyer. In this way, the current "traditional" manufacturers are becoming multimedia representatives of information using the Internet or own a commercial database. It must be borne in mind that information technologies have a number of advantages that are reflected in /8/:

- Modernization of business activities by reducing the number of employees,

- Better financial operations of the company,

- Rational use of capacity, resources and energy,

- Quality distribution of materials, goods and services.

This all affects the improvement of the situation of companies in the business. Information technologies significantly change the competitive prospects of all business processes during the manufacturing process, but also in the process of service delivery companies /5/. The application of information technologies and the development of management information system enterprise, have a key role in achieving maximum effects of process reengineering. The development of competition and the weak global economy caused by the need to analyze the process of doing business - which includes the organizational structure and personnel. Information technology to human resources and organizational change is one of the key elements in the process of re-engineering. It is used in all its phases, and particularly pointed out in the following activities:

- Defining business strategy,

- Identification of other key elements of BPR's,

- Identification and selection process for the redesign,

- Analysis of the structure and flow of existing business processes,

- Measure the performance of existing processes,

- Designing and prototyping of new processes,

- Implementation and operationalization of new and changed processes,

- Communication between project team members.
Business logic causes the need for restructuring of the company, causing the need for the distribution of information, which requires infrastructure, which exists in some form, but it is necessary to connect and modernize, while it does not matter how we do it. The development of information technologies has enabled the emergence of the computer as the proponent of the decision $/ 7 /$. The computer receives a personal "intelligence", knowledge and manner of use of this knowledge, however, can do the decision-making process. All phases of the decision-making process, including now and the selection phase, carried out using a computer (software packages). So, at this level, computer (on the basis of a computer program, information and knowledge) has the role of proponents of decisions that a person can accept or not to accept. Such shims are called expert systems $/ 7 /$.

In order for a business system to define your goals and focus its activity on their realization, it is necessary to have a system of information, which provides the necessary inputs for the normal functioning of the business /9/. The harmonization of market conditions with the abilities and skills of the business system is the primary condition for planning objectives, policies and strategies as well as for the development of appropriate plans and programs of the business system. In the business system, information system provides: collecting data from sources in the business system and outside it, classification, coding and indexing of data from the source system in the business and outside it, storing and updating data, retrieving stored data, data processing, interpretation of information, making reports and the distribution of decision-making bodies.

Information system not only provides information for planning, execution and control, but also performs a number of other creative and technical tasks that are performed in the classical system of organizational functions of planning and control and so brings significant changes to the organizational structure and management system. Advantages of computer networks are: increasing the productivity of 
labor, exchange of documents in a faster, safer and easier way, facilitated communication at the firm level, the ability to save all your important information in one place, so that they are better organized and, if necessary, available to all computers on the network, centralized print all types of documents, access to the internet and use e-mail with all the computers in the network $/ 9 /$.

Investing in the development of information technology should always be correlated with the aim of increasing efficiency and effectiveness of operations and business systems. The favorable general social climate, access and attitude of society, its individuals to information, the openness of the social system, the quality of its organization, particularly the economic system, stability of economic conditions, the ability to procure and use of new information technologies and IT culture, in addition to the required quality of organization of the business system, positive effect on the development of information systems /2/.

\subsection{Enterprises and their innovation activities}

\subsection{Enterprises and their innovation activities}

The innovative activity presents one of the main activities for the achievement of the organizational success of the enterprise, and for the overall and inclusive economic development of the country /2/. Nowadays, enterprises are not only required to do imitations but also to do adaptations and innovations in order to face the market competition and market turbulence. In order to achieve such a success, enterprises initially need to make investments in Research and Development of new products and services, which means bringing innovations in market.

Innovation is seen as the main leader toward productivity of the enterprise. Innovation helps businesses to improve the way the products and services are produced and distributed, or to present totally new products in the market.
Researches show that $12 \%$ of circulations of the SMEs in EU come from the new products and services or from the visibly improved products and services (European Commission, 2007, p.5). Data show that innovative enterprises have a better performance and a faster growth rate compare to non-innovative enterprises. Innovation is well defined as a successful utilization of ideas - or turning the ideas into profitable products, processes, services, or business practices. Thus, nowadays enterprises need to be more innovative each day.

Some of the characteristics of an innovative enterprise are: the open approach and the orientation toward changes, which represent the condition for the highest scale of innovation inside the enterprise. The main factor of the innovative enterprise and it's strategic resource of innovation is her competitiveness. The qualities of competiveness are:

- Orientation toward market and positive attitude toward changes in technology

- Acceptance of the risk, and tolerance of mistakes during the application of innovative technology

- Development of the employees in using technology

- Maximal decentralization

- Intense communication

- Network structure, team work, and flexibility

- Application of integration mechanisms in the structure of the enterprise

Modern Enterprise uses different organizational mechanisms to encourage and support innovations. The main mechanism is the R\&D sector, which is the eldest organizational mechanism, is to encourage innovations within the enterprise, to development new products, and to improve existing products. The formation of this sector offers the enterprises the opportunity to take the advantage of competition through sophisticated solutions based on advanced technology. This sector enables the enterprises to:

- Manage the basic researches in the framework of strategic aims of the enterprise 
- Manage the long term research projects which are consistent with strategic aims of the enterprise

- Keep the pace of technology-scientific progress which can be considered by enterprises as an opportunity or a threat $/ \mathbf{6} /, / \mathbf{1 0} /$.

The management of basic researches is necessary for the enterprises because each time they are required to be competitive with products and services with the aim of the accomplishment of long term existence strategy. Thus, enterprises that understood that only innovative solution can survive them should make the efforts to manage the process of research and development to the highest qualities. The qualitative management depends on the long term projection of the process in accordance with strategic plan of competition of the enterprise. In addition, the projection of the consistent process with the strategy of the enterprise should internally foresee the technological progress and use the advanced technology in order to have more alternatives for the opportunities for the creation of the success and productivity of the enterprise through $R \& D$ and creation of new products and services. /11/ Until now, the studied associated with the relation between information technology and productivity of the enterprise have shown positive impact on business or enterprise operations $/ \mathbf{1 2}$. . Thus, it is especially important for the enterprises to be competitive in the market and to base that competiveness in the innovative advantages mainly in the below industries: automobile industry, airplane-air, as well as other industries such as clothing industry, agriculture industry, and other industries. Every enterprise, no matter it's form and size, make the market positioning bases on innovative products $/ \mathbf{1 3} /$.

\section{Empirical Analysis/ Results}

The scientific methodology used in this work is the quantitative methodology with the deductive approach because it is intended to support the existing theory over the information technology and innovative processes. Whereas the research methodology, this work communicate the comparative methods and cause and consequence method, because it is desired to highlight the comparison of innovative processes or the presentation of innovative products and services between the enterprises that produce the software and those which do not produce it, which mean other producers. Then, there are analysis in order to see the impact and causes in innovation processes which are occurring in the above mentioned industries. The quantitative data that are used in this work are taken from the Kosovo Agency of Statistics and have to do with the progress of the innovative processes and information technology in Production Enterprises in Kosovo. Statistic methodologies are used for the analysis the frequency of the variable, the analyses of the correlation, and the analysis of the regression of the variable, categories which have to do with innovation processes through information technology.

Hence, the research variables are the business activities, Innovation in communication information and technology, innovative activities are a business entity performed in the period of 2010-2017, EI and Investment in innovation. The hypothesis is:

H1 The quality of innovation ICT in production industry which depends on business activities and innovative effectiveness.

H2 The effects of the investments in increasing the innovation technology in Kosovo Enterprises.

To test the hypothesis, we used the following statistical tests:

1) One-Way Anova;

2) The Spearman correlation coefficient.

3). Regression analyses.

Table. 1 Markets that have placed technological innovation in the field of production and services as well as software industry

\begin{tabular}{|c|c|c|c|}
\hline $\begin{array}{l}\text { Business } \\
\text { Activity }\end{array}$ & $\begin{array}{l}\text { Kosovo } \\
\%\end{array}$ & $\begin{array}{l}\text { Europe } \\
\%\end{array}$ & World \% \\
\hline$S$ & 8,4 & 14,6 & 18 \\
\hline $\mathrm{P}$ & 0,3 & 2,2 & 5,6 \\
\hline
\end{tabular}


Source: Adapt from www.oecdraportof question regarding the placed technological innovation data from year 2015 and Statistical online data from ASK 2017.

Table 2. Testing the equality of proportion when it comes to product innovation between companies in their field

\begin{tabular}{|c|c|c|c|c|c|c|c|c|c|c|c|c|}
\hline \multirow{3}{*}{$\begin{array}{l}\text { Innovation in COMMUNICA- } \\
\text { TION INFORMATION AND } \\
\text { TECHNOLOGY }\end{array}$} & \multicolumn{12}{|c|}{ The business sector } \\
\hline & \multicolumn{3}{|c|}{ Manufacturer } & \multicolumn{3}{|c|}{ Services } & \multicolumn{3}{|c|}{ Trade } & \multicolumn{3}{|c|}{ Total } \\
\hline & 0 & 1 & 2 & 0 & 1 & 2 & 0 & 1 & 2 & 0 & 1 & 2 \\
\hline $\begin{array}{l}\text { Computer based system [electronic } \\
\text { data transfer] }\end{array}$ & 61 & 3 & 6 & 10 & 0 & 0 & 59 & 2 & 9 & $\begin{array}{l}86.67 \\
\%\end{array}$ & $3.33 \%$ & $\begin{array}{l}10.00 \\
\%\end{array}$ \\
\hline Efficient energy utilization & 62 & 3 & 5 & 9 & 0 & 1 & 65 & 2 & 3 & $\begin{array}{l}90.67 \\
\%\end{array}$ & $3.33 \%$ & $6.00 \%$ \\
\hline $\begin{array}{l}\text { Quality, standard and product } \\
\text { certification }\end{array}$ & 55 & 6 & 9 & 10 & 0 & 0 & 62 & 2 & 6 & $\begin{array}{l}84.67 \\
\%\end{array}$ & $5.33 \%$ & $\begin{array}{l}10.00 \\
\%\end{array}$ \\
\hline
\end{tabular}

Source: Data base of the study

The above table shows that there are very small investments in innovations related to communications and information technology in enterprises of Kosovo. Hence, it can be concluded that production companies are those that have a very small investment in IT compared with trading companies which invest in IT the most. Thus, enterprises in Kosovo invest
As we can see the table 1 show us that in the Kosovo are a low level of technological placed on the market with comparison with firms in the Europe and World.

Table 3 The value on innovation activities at the enterprises in Kosovo

\begin{tabular}{|c|l|c|l|}
\hline $\begin{array}{c}\text { Investment } \\
\text { in innova- } \\
\text { tion }\end{array}$ & Industry & Mean (000) & Sdev \\
\hline \multirow{2}{*}{ IRD R\&D } & $\mathrm{S}$ & 7986,69 & \\
\hline & $\mathrm{P}$ & 928,26 & \\
\hline \multirow{2}{*}{ ERD R\&D } & $\mathrm{S}$ & 2181,65 & \\
\cline { 2 - 4 } & $\mathrm{P}$ & 701,14 & \\
\hline \multirow{2}{*}{ AM } & $\mathrm{S}$ & 3293,2 & \\
\hline & $\mathrm{P}$ & 31866 & \\
\hline \multirow{2}{*}{ AEKAIA } & $\mathrm{S}$ & 1164,17 & \\
\hline & $\mathrm{P}$ & 163,31 & \\
\hline \multirow{2}{*}{ Total } & $\mathrm{S}$ & 14625,7 & \\
\hline & $\mathrm{P}$ & 33658,71 & \\
\hline
\end{tabular}

Source: Data base of the study

The results on the following table show the effects of innovation through the companies that produce software as well as the ones that
$10 \%$ in innovations within the information systems, $6 \%$ innovations in energy efficiency, and $10 \%$ in the quality of products based on ICT. The following table shows that the innovation activities that are implemented by production companies in general, in a seven years' period. 
characteristics of the results is that respective companies that produce software are more efficient in the category of innovation rather than those who do not produce, however also companies that do not produce respective software have significance of innovation category since that also they use some respective innovation technology. For more information, see the results at the table below.

Table 4. The modality average of the effects of technological innovation between companies in Kosovo

\begin{tabular}{|c|l|r|}
\hline \multirow{2}{*}{ EI } & Industry & $\begin{array}{c}\text { \% Modality } \\
\text { average }\end{array}$ \\
\hline \multirow{2}{*}{ IRPS } & $\mathrm{S}$ & 48,88 \\
\cline { 2 - 3 } & $\mathrm{P}$ & 43,86 \\
\hline \multirow{2}{*}{ ROPP } & $\mathrm{S}$ & 50,65 \\
\cline { 2 - 3 } & $\mathrm{P}$ & 38,95 \\
\hline \multirow{2}{*}{ IINMIMSH } & $\mathrm{S}$ & 52,8 \\
\cline { 2 - 3 } & $\mathrm{P}$ & 31,8 \\
\hline \multirow{2}{*}{ IQPS } & $\mathrm{S}$ & 62,08 \\
\cline { 2 - 3 } & $\mathrm{P}$ & 50,05 \\
\hline \multirow{2}{*}{ IFPS } & $\mathrm{S}$ & 58,1 \\
\cline { 2 - 3 } & $\mathrm{P}$ & 37,85 \\
\hline \multirow{2}{*}{ TIPC/VS } & $\mathrm{S}$ & 49,6 \\
\cline { 2 - 3 } & $\mathrm{P}$ & 38,08 \\
\hline \multirow{2}{*}{ RLCUP } & $\mathrm{S}$ & 44,05 \\
\cline { 2 - 3 } & $\mathrm{P}$ & 36,48 \\
\hline \multirow{2}{*}{ RCMEUP } & $\mathrm{S}$ & 25,33 \\
\cline { 2 - 3 } & $\mathrm{P}$ & 35,9 \\
\hline \multirow{2}{*}{ REI } & $\mathrm{S}$ & 35,9 \\
\cline { 2 - 3 } & $\mathrm{P}$ & 12,58 \\
\hline \multirow{2}{*}{ IHSE } & $\mathrm{S}$ & 38,63 \\
\cline { 2 - 3 } & $\mathrm{P}$ & \\
\hline \multirow{2}{*}{} & & \\
\hline
\end{tabular}

Source: Data base of the study

The results shown in the table no.5 firstly reveal the increase in number of product or service Gama by the software enterprises in Kosovo is evaluated moderately high by $48.88 \%$. In the same category of variables, from the side of the other producers, the increase in number of product or service Gama is evaluated with $43,86 \%$. Hence, it can be concluded that Kosovo producers make the satisfied growth of their products or services. The second category of the innovation, which is the replacement of old products/process by software producers, is happening in 50,65\% of the cases. Other producers have made many product/service replacement expressed in the rate of $38,95 \%$. Considering the above data, it can be concluded that the production sector in Kosovo base its processes in the replacement of the prod- ucts in the proportion of $1: 3$, or around $54 \%$ of producers do not do the replacement of products or processes compare to $46 \%$ which do the replacement. The third category, which is the category of software producers which have difficulties in new markets penetration and difficulties in increasing the market share, is evaluated $52,8 \%$. This percentage shows that nearly half of software producers have problems with new market penetration which are more open compare to other producers which are evaluated with $31 \%$ which means that around $69 \%$ of other producers consider the new market penetration as their major difficulty. The following category reveals that percentage of quality improvement of the products and services from the perspective of software producers and other producers. Hence 
$62,08 \%$ SP (Software Producers) improve the quality of their products each year compare to $50,05 \%$ of OP (Other Producers) which do the same. Regarding the production/services flexibility increase rate, in the perspective of software producers we have $58,1 \%$ increase rate compare to $41,9 \%$ which do not do the increase. On the other hand, other producers $37,85 \%$ increase the flexibility in production/services. (Table 3). The data presented at the table, show that performance of innovation activities have been intensified in the software
industry.Finally we can conclude that regarding the results we have large effects of innovation in two different fields, but the $S$ has bigger business intensity than $P$.

In order to have the best representation of the aforementioned categories and variables, in the following table we will see the correlation of analysis. In this table, it is pretended to get the highlight the relationship, the relationship through the coefficient of correlation. The line of Correlation Analysis is in the service to base the hypothesis testing.

Table 5. The correlation of research variables of EI and R\&D

\begin{tabular}{|c|c|c|c|c|c|c|c|c|c|c|c|}
\hline & & & IRPS & ROPP & $\begin{array}{c}\text { INMI } \\
\text { M }\end{array}$ & IQPS & IFPS & IRD & ERD & $\begin{array}{c}\text { AEKA } \\
\text { I }\end{array}$ & $\begin{array}{c}\text { AME } \\
S\end{array}$ \\
\hline \multirow[t]{14}{*}{$\begin{array}{l}\text { Spearman' } \\
\text { s rho }\end{array}$} & IRPS & $\begin{array}{l}\text { Correla- } \\
\text { tion Coef- } \\
\text { ficient } \\
\text { Sig. (2- } \\
\text { tailed) }\end{array}$ & 1,000 & ,041 & ,035 & ,218 & ,607* &,- 068 &, $579^{* *}$ & $397^{\prime * 4}$ & ,003 \\
\hline & ROPP & $\begin{array}{l}\text { Correla- } \\
\text { tion Coef- } \\
\text { ficient }\end{array}$ &, $257^{*}$ & 1,000 &, $365^{* *}$ & , $784^{-}$ & 0,000 & , $913^{* *+}$ & 200 & -157 &,$- 784^{* *}$ \\
\hline & & $\begin{array}{l}\text { Sig. (2- } \\
\text { tailed) }\end{array}$ & 041, & & 003, & ,000 & 1,000 & ,000 & 113 & ,216 & ,000 \\
\hline & $\begin{array}{c}\text { INMI } \\
\text { M }\end{array}$ & $\begin{array}{l}\text { Correla- } \\
\text { tion Coef- } \\
\text { ficient }\end{array}$ & , 264 &, $365^{* *}$ & 1,000 & $\begin{array}{c}- \\
, 556^{* *}\end{array}$ & 169 & ,217 &, $641^{* *}$ &,$- 514^{* *}$ &,$- 654^{* *}$ \\
\hline & & $\begin{array}{l}\text { Sig. (2- } \\
\text { tailed) }\end{array}$ & ,035 & 003, & & ,000 & 182 & ,086 & ,000 & 000, & 000, \\
\hline & IQPS & $\begin{array}{l}\text { Correla- } \\
\text { tion Coef- } \\
\text { ficient }\end{array}$ & ,218 &,$- 784^{* *}$ &,$- 556^{* *}$ & 1,000 &, $331^{* *}$ & , $656^{-}$ & 0,000 & ,218 &, $667^{* *}$ \\
\hline & & $\begin{array}{l}\text { Sig. (2- } \\
\text { tailed) }\end{array}$ & 083, & ,000 & 000, & & 008, & ,000 & 1,000 & 083, & 000, \\
\hline & IFPS & $\begin{array}{l}\text { Correla- } \\
\text { tion Coef- } \\
\text { ficient }\end{array}$ & , $607^{* *}$ & 0,000 & 169, &, $331^{* *}$ & 1,000 &, $247^{*}$ &, $649^{* *}$ & 130, & 0,000 \\
\hline & & $\begin{array}{l}\text { Sig. (2- } \\
\text { tailed) }\end{array}$ & ,000 & 1,000 & 182 & ,008 & & ,049 & 000, & 306 & 1,000 \\
\hline & IRD & $\begin{array}{l}\text { Correla- } \\
\text { tion Coef- } \\
\text { ficient }\end{array}$ &,- 068 & ,913 & ,217 & ${ }^{-}$ &, $247^{*}$ & 1,000 & ,211 & 120, &,$- 621^{* *}$ \\
\hline & & $\begin{array}{l}\text { Sig. (2- } \\
\text { tailed) }\end{array}$ &, 595 & 000, & ,086 & ,000 & 049, & & ,094 & 343, & ,000 \\
\hline & ERD & $\begin{array}{l}\text { Correla- } \\
\text { tion Coef- } \\
\text { ficient }\end{array}$ &, $579^{* *}$ & 200 &, $641^{* *}$ & 0,000 & ,649** & ,211 & 1,000 &,$- 312^{*}$ &,$- 408^{* *}$ \\
\hline & & $\begin{array}{l}\text { Sig. (2- } \\
\text { tailed) }\end{array}$ & ,000 & 113 & ,000 & 1,000 & , 000 & ,094 & & ,012 & ,001 \\
\hline & AEKAI & Correla- & , 397" & 157,- &,$- 514^{* * *}$ & 218, & 130, & 120, &,$- 312^{*}$ & 1,000 & ,582** \\
\hline
\end{tabular}




\begin{tabular}{c|c|c|c|c|c|c|}
\hline, 000 &, 083 &, 306 &, 343 &, 012 & &, 000 \\
,$- 654^{* *}$ &, $667^{* * *}$ & 0,000 & - & - &, $582^{* * *}$ & 1,000 \\
& & &, $621^{* *}$ &, $408^{* * *}$ & & \\
&, 000 & 1,000 &, 000 &, 001 &, 000 &
\end{tabular}

through computer hardware and software, while is not in positive. Hence, the result of aforementioned quality is $-582^{* *}$. In two other cases, we may have the base to approve $\mathrm{H} 1$ There is a low level of investments in Research and Development of innovative activities in Kosovo, and $\mathrm{H} 2$ The investments in innovation technology improve the relation between innovation effects and information technology in Kosovo's Enterprises.

In continuance, we will show the results which have to do with the analysis of correlation of research variables of this work. Moreover, the paper will closely show the correlation between variables.

Table 6. The main correlation of crucial research variables

\begin{tabular}{|c|c|c|c|c|c|c|}
\hline \multicolumn{2}{|c|}{ Variables } & BA & ICIT & IAP & EI & II \\
\hline \multirow[t]{2}{*}{ BA } & Correlation & 1,000 &, $555^{* *}$ &, $309^{*}$ &, $336^{* *}$ &, $146^{* *}$ \\
\hline & $\begin{array}{l}\text { Sig. (2- } \\
\text { tailed) }\end{array}$ & & ,000 & 013 & 007 & \\
\hline \multirow[t]{2}{*}{ ICIT } & $\begin{array}{l}\text { Correlation } \\
\text { Coefficient }\end{array}$ &, $555^{* *}$ & 1,000 & 067 & 123 &, $326^{* *}$ \\
\hline & $\begin{array}{l}\text { Sig. (2- } \\
\text { tailed) }\end{array}$ & ,000 & & 601 & ,331 & 211 \\
\hline \multirow[t]{2}{*}{ IAP } & $\begin{array}{l}\text { Correlation } \\
\text { Coefficient }\end{array}$ & ,309* & ,067 & 1,000 & $309^{*}$ & $109^{* *}$ \\
\hline & $\begin{array}{l}\text { Sig. (2- } \\
\text { tailed) }\end{array}$ & 013 & 601 & & ,013 & .004 \\
\hline \multirow[t]{2}{*}{ EI } & $\begin{array}{l}\text { Correlation } \\
\text { Coefficient }\end{array}$ & ,336** & 123 & ,309* & 1,000 &, $049^{* *}$ \\
\hline & $\begin{array}{l}\text { Sig. (2- } \\
\text { tailed) }\end{array}$ & ,007 & ,331 & ,013 & & .224 \\
\hline \multirow[t]{2}{*}{ II } & $\begin{array}{l}\text { Correlation } \\
\text { Coefficient }\end{array}$ & , $146^{* *}$ & $326^{* *}$ & , $109^{* *}$ &, $049^{* *}$ & 1,000 \\
\hline & $\begin{array}{l}\text { Sig. (2- } \\
\text { tailed) }\end{array}$ & 211 & & .004 & .224 & \\
\hline
\end{tabular}




\begin{tabular}{|l|r|r|r|r|}
\hline Model & R & R Square & $\begin{array}{c}\text { Adjusted } \\
\text { R Square }\end{array}$ & $\begin{array}{c}\text { Std. Error } \\
\text { of the } \\
\text { Estimate }\end{array}$ \\
\hline 1 &, $596^{\mathrm{a}}$ &, 355 &, 311 &, 58222 \\
\hline
\end{tabular}

The above model reveals that the independent variables can forecast the depended variables by $59,6 \%$, or more exactly $35 \%$, because $R$ Square is ,355. According to B Krasniqi 2012, in social sciences the accepted model is also the model which shows the results not lower than ,100. Based on this conclusion, that model can be used to test this phenomena. In continence, we will show the results which have to do with the values of regression model coefficient.

Table 8 The coefficients value of testing model

\section{Coefficients $^{\mathrm{a}}$}

\begin{tabular}{|c|c|c|c|c|c|c|}
\hline \multirow[t]{2}{*}{ Mode } & & \multicolumn{2}{|c|}{$\begin{array}{l}\text { Unstandardized Coef- } \\
\text { ficients }\end{array}$} & \multirow{2}{*}{$\begin{array}{c}\text { Standard- } \\
\text { ized Coef- } \\
\text { ficients } \\
\text { Beta }\end{array}$} & \multirow[t]{2}{*}{$\mathrm{t}$} & \multirow[t]{2}{*}{ Sig. } \\
\hline & & B & Std. Error & & & \\
\hline \multirow[t]{5}{*}{1} & ICIT & ,500 & ,325 & & 1,536 & , 130 \\
\hline & $\mathrm{BA}$ & 750 & 178 & 750 & 4,207 & ,000 \\
\hline & IAP & $-1,250$ & 309 &,- 870 & $-4,048$ & ,000 \\
\hline & EI & ,500 & 252 &,- 348 & $-1,983$ & ,052 \\
\hline & II & ,545 & ,325 & 1,043 & 4,609 & ,000 \\
\hline
\end{tabular}

$B_{0}$ Coefficient in our case Bicit tell the strength of depended variable ,500 with accuracy of ,130. $\mathrm{B}_{1}-\mathrm{B}_{\mathrm{ba}}$ tells that business activities are effected and depend on $75 \%$ by innovation in ict, considering its value of ,750 and sig, 000. The depended variable of period 2010-2017 of innovation activities do not affect the depended variable, because the innovation happen often within the year and this variable should tell the results of only one year period. The innovation effects have impacts on innovations of ICT with the accuracy of ,052 and variability of $50 \%$. The innovation investment variable effects the forecasting of ITC innovations, shown through variability of 54,5 and sug, 000 . Thus, the model of regression and its values can be uses in the work of hypothesis testing. Hence, by derivation, we came up with the following formula of hypothesis testing:

Impact IT in Innovation $=0,500+0,750$ -

$$
1,250+, 500+, 545
$$

Table 9 Anova model of testing model

\begin{tabular}{|c|c|c|c|c|c|c|}
\hline \multicolumn{2}{|c|}{ ANOVA } \\
\hline \multicolumn{2}{|c|}{} & $\begin{array}{c}\text { Sum of } \\
\text { Squares }\end{array}$ & df & $\begin{array}{c}\text { Mean } \\
\text { Square }\end{array}$ & F & Sig. \\
\hline $\begin{array}{c}\text { Vendimet } \\
\text { strategjike }\end{array}$ & $\begin{array}{c}\text { Between } \\
\text { Groups }\end{array}$ & 6,000 & 1 & 6,000 & 6,571 &, 014 \\
\cline { 2 - 7 } & $\begin{array}{c}\text { Within } \\
\text { Groups }\end{array}$ & 42,000 & 46 &, 913 & & \\
\hline
\end{tabular}


Value $\mathrm{f}$ 6,571 for H1 The quality of innovation ICT in produce industry depend of business activity and innovative effectiveness show $\mathrm{p}$ 0,014 . Hypothesis is approved

Value $f$ 6,571 for H1 The investments in innovation technology increased innovation effects in Kosovo Enterprises. show p 0,056. Hypothesis is approved

\section{Conclusion}

Business environment is becoming more and more turbulent because of fast development in information communication technology and in general technology. No manager can neglect the impact of such development on his industry and organization. In such business environment, imagination, creativity, innovation and courage become more and more important as the is no general rule for success.

In the fast changing business world, innovation in ICT and in general technology has become mainstay of every organization. The nature of global economic growth has been changed by the speed of innovation in ICT, which has been made possible by rapidly evolving information technology and technology in generally, shorter product lifecycles and a higher rate of new product development.

The need for organization to innovate and to gain benefits of innovation in ICT is stressed throughout the innovation and information communication technology in generally literature. This need comes from increasing competition and customer demands. Innovations of ICT involve new working methods, new ideas, new products, new processes, new form of organization and new management.
In this paper has been find the positive relation between variables innovation of information technology with all business activity in produce sector of Kosovo as a SEE country. This study gives us opportunity to recommend that all business must in their daily activity applied innovation in business process on the way to respond customer demands. Also regarding with research question of paper which is the level of placed technology innovation in field of production sector in Kosovo is very low and in relation between other SEE, OECD countries is in rapport 1:80. This paper strongly recommended that the state government policy must be oriented on increasing the innovation by giving the extra foundation for research and development for all business if they want to be part of development countries. Also and business must have special sector for research and development on the way to create new product and services.

Finally, recommendation basic of this paper is that the Public and Private organizations should take appropriate steps to develop and improve new information technologies by creating long-term policies and strategies derived from market needs.

Notes

/1/ Berisha-Shaqiri, A., Miftari, I., Berisha-Namani, M. (2015). "Information Technology and the Digital Economy," Mediterranean Journal of Social Sciences, vol. 6, no. 6, pp. 78-83.

/2/ Ahuja, G., Lampert, C. M., "1. Ahuja, G.(2001). L Entrepreneurship in the large corporation: A longitudinal study of how established companies create breakthrough inventions," Strategic Management Journal, vol. 22, no. 6-7, p. 521-543. 
/3/ Maravi M.U., Križaj D., Lesjak M. (2015). Innovation in Slovenian Tourism organizations'," Inn Tourism and Hospitality Management, vol. 21, no. 1, p. 52 , 2015.

/4/ Tidd J., Bessant J., and Pavitt K. (2005). Managing Innovation, Integrating Technological, Market and Organizational Change, Third Edition ed., John Wiley \& Sons Ltd.

/5/ Bhatt, D. G. i Emdad, F. A. (2010). "An empirical examination of the relationship between information technology (IT) infrastructure, customer focus, and business advantages," Journal of Systems and Information Technology, vol. 12, no. 1, pp. $4-16$.

/6/ Bovée, L. C. i Thill, V. J. (2011). Suvremena poslovna komunikacija, vol. 10, Zagreb: Mate, p. 750.

/7/ Seonghun Min and Sang Su Keum (2016). "Does Capital Structure Change the Value of Real Estate," INFORMATION-An International Interdisciplinary Journal, vol. 19, pp. pp.57095714.

/8/ Jaklič A., Damijan J. P., Rojec M., Kunčič A. (2014). "Andreja Jaklič, Jože P. Damijan, Matij
Relevance of innovation cooperation for firms' innovation activity: the case of Slovenia," Andreja Jaklič, Jože P. Damijan, Matija Rojec E Aljaž Kunčič (2014) Relevance of innovation cooperaEconomic Research-Ekonomska Istraživanja, vol. 27, no. 1, p. p.646.

19/ Cozzarin B.P. (2006). "Are world-first innovations conditional on economic performance?, Tehnovation, article in pres,"

/10/ Covin, J. G., Slevin, D. P. (1989). "Strategic Management of Small Firms in Hostile and Benign Environments," Strategic Management Journal, vol. 10, no. 1, p. 75-87.

/11/ Huergo E. (2006). "The role of technological management as a source of innovation: Evidence from Spanish manufacturing firms," Research Policy, vol. 35.

/12/ Horvat, Đ., Perkov, D., Trojak, N. (2012). "Strategijsko upravljanje i konkuretnost u novoj ekonomiji," Edukator

/13/ N.Stojčić, I. Hashi (2014). " Firm Productivity and Type of Innovation: Evidence from the Community Innovation Survey 6," vol. 16, pp. 121-146. 